\title{
Developing Learning Kit of Geometry for Vocational School Grade X Based on Multiple Intelligence Theory
}

\author{
Aep Sunendar \\ Mathematics Education Department Majalengka University, Majalengka, Indonesia \\ aepfromciamis@gmail.com \\ Ali Mahmudi \\ Mathematics Education Department Yogyakarta State University, Yogyakarta, Indonesia \\ ali_uny73@yahoo.com
}

\begin{abstract}
This study aims to develop a learning kit of geometry for Indonesian vocational schools, grade $\mathrm{X}$ based on the multiple intelligence theory. This research and development used the 4D model suggested by Thiagarajan, Semmel and Semmel (1974) consisting of four stages that are: define, design, development, and disseminate. The data were analyzed by converting the actual scores obtained into a qualitative five category scale. The effectivity was analyzed by determining the percentage of students' who completed a test and the percentage of students in each category as collected by the questionnaires. The Lesson Plan and worksheets were found to be valid. The results showed that the Lesson Plan and worksheet were practical based on the result of implementation, teacher's assessment and students' assessment. Furthermore, the Lesson Plan and worksheet were regarded as effective as reported by the students' increasing achievement of spiritual attitudes, social attitudes, and knowledge competences. However, in terms of skill competences, the Lesson Plan and worksheet were not effective.
\end{abstract}

Keywords: Learning kit, Multiple Intelligences Theory, Geometry, Indonesian secondary vocational school.

\section{Introduction}

According to the Law of the Republic of Indonesia number 20 of 2003, article 1 paragraph 1,

Education means conscious and well-planned effort in creating a learning environment and learning process so that learners will be able to develop their full potential for acquiring spiritual and religious strengths, develop self-control, personality, intelligence, morals and noble character and skills that one needs for him/herself, for the community, for the nation, and for the State (IMNE, 2003, p. 6)

But in reality, education in Indonesia has not achieved these goals. This can be seen from the UNESCO Educational for All Monitoring Report (UNESCO, 2012) which reported that Indonesia was ranked 64th out of 120 countries in measuring the quality of education. This means that the quality of education in Indonesia was still low.

Also monitoring of the mathematics subject shows achievements that have not been optimal, as is indicated by the results of TIMSS and PISA and reported in Permendikbud 
number 60 (MECRI, 2014, p.2). Yet mathematics is an important subject, as NCTM (2000, p.5) states that in an ever-changing world those who understand and can do the mathematics will have more opportunities and choices in determining their future. In line with this, Permendikbud number 60 (MECRI, 2014, p.323) states that to master and create technology in the future, it takes mastery and understanding of mathematics that is strong from an early age. Therefore, it is important for vocational students especially in the technology field to master mathematics.

However, based on the results of observations conducted at the State Vocational High School 1 Padaherang, students' mathematics learning achievement is less than optimal. This is shown from the completeness of students who only $20 \%$ at the end of learning and the results of the National Examination (UN) which decreased in 2012/2013. The decline in UN results for mathematics subjects can be seen in Table 1 below.

Table 1.

Mathematics National Examination (UN) Results Data (Source from BSNP, 2012 \&2013)

\begin{tabular}{ccc}
\hline Exam Value & Years 2011/2012 & Years 2012/2013 \\
\hline Classification & $\mathrm{A}$ & $\mathrm{D}$ \\
Mean Score & 9,43 & 4,64 \\
Lowest Score & 8,50 & 3,00 \\
Highest Score & 10,00 & 9,25 \\
\hline
\end{tabular}

From Table 1, it can be seen that the average score on the National Examination in 2012/2013 was 4.64 which had dropped drastically from the previous year's average of 9.43 . From the results of the National Examination, it was concluded that mathematics learning achievement had decreased.

SMK Negeri 1 Padaherang is one of the vocational schools that implemented the 2013 Curriculum. Based on Permendikbud number 65 (MECRI, 2013, p.1) states that the learning process in educational units is organized interactively, incentive, fun, challenging, motivating students to actively participate and provide space sufficient for initiative, creativity and independence in accordance with the talents and interests, and the physical and psychological development of students. However, based on observations it appeared that students were less enthusiastic in learning mathematics, and students tended to get bored quickly. Students tended to prefer productive subjects compared to other subjects including mathematics. This is hypothesized the reasons are the learning of mathematics is monotonous and the pedagogy is still teacher-centered.

Current Indonesian teaching practices have been described as the teacher being the center of teaching activities and giver of knowledge, while the students are seen as empty glasses that must always be filled with knowledge (Suyono \& Hariyanto, 2014). According to Yaumi (2012), a new student-centered approach is needed based on the theory that students are active participants in the learning process and that this should be fully integrated into the learning implementation plan. To maximize student learning, planning of learning must pay attention to learning styles and multiple intelligences (Moore, 2009). Moore emphasizes that multiple intelligences can be used in planning learning to achieve the expected competencies, including in mathematics learning. Hoerr (2000) states that teachers who use multiple 
intelligences can give students the opportunity to use their strongest intelligence to demonstrate what they are learning. However, these claims should be questioned in light of criticisms of the theory (Carson, 2003).

\section{Review of Literature}

Compound intelligence is used to mean the multiple intelligences proposed by Gardner. In the first edition in his book "Frame of Mind", Gardner describes seven types of intelligence namely logical-mathematics, verbal-lingstic, visual-spatial, musical, bodily-kinesthetic, interpersonal, and intrapersonal. Then in the second edition he added two types of intelligence namely naturalist and existential (Calik \& Birgili, 2012). However, Connell (Yaumi, 2012, p.229) states that Gardner himself still considers existential intelligence as a half or imperfect intelligence due to its physiological location in the human brain. So, in this study, the meaning of multiple intelligences is the eight intelligences expressed by Gardner namely logicalmathematics, verbal-linguistic, visual-spatial, musical, bodily-kinesthetic, interpersonal, intrapersonal and naturalist.

In Bas and Beyhan's research (2010) the results of their research showed that there was an influence from multiple intelligences on learning when supported by project-based learning. This learning influenced student achievement and attitudes in their English lessons. Previous research by Xie and Lin's (2009) showed that polytechnic students in Taiwan in classes that implemented multiple intelligence-based learning were significantly better than students in classes which did not when working on project design tasks.

Temur's (2007) study of the effect on learning by teaching based on multiple literacy theories on mathematics learning achievement of fourth-grade elementary school students at Gazi University Foundation Private Primary School. The results of the research showed that the students' mathematics learning outcomes increased after implementing mathematics learning based on the multiple intelligences theory.

The multiple intelligence potential that students have should be used as an opportunity to create interesting learning contexts. Interesting learning requires careful planning supported by adequate learning media. However, based on the results of the interviews, teachers have not actively developed all the potential possessed by the students including multiple intelligences, nor the implementation of the 2013 curriculum. The teachers still have difficulties in developing learning tools based on the 2013 Curriculum and there are no mathematics learning devices based on multiple intelligence theories developed especially at the secondary vocational school level. Therefore, the development of mathematics learning devices based on the multiple intelligence theory is oriented towards achieving competence according to the 2013 Curriculum is proposed as a solution. Based on this, the researcher conducted a research study on the development of mathematics learning devices based on multiple intelligence theories oriented to the achievement of competencies according to the 2013 curriculum of SMK students of class $\mathrm{X}$ in semester 2. 


\section{Methodology}

This study uses the developmental model discussed by Thiagarajan, Semmel and Semmel (1974) and called the 4D model and consists of 4 stages, namely: define, design, development, and disseminate (Thiagarajan, Semmel \& Semmel, 1974, p.5).

\section{Research Procedure}

The first stage is defining which establishes and defines the requirements for development. It consists of five stages of analysis: namely preliminary analysis, curriculum analysis, student analysis, material analysis, and analysis of the final goal. The preliminary analysis aims to obtain information about the tools of mathematics learning in the field. The curriculum analysis aims to establish the competencies in which learning tools are developed. The student analysis seeks the characteristics of students at the level of vocational high school (SMK). These characteristics include initial abilities, background, knowledge, students' cognitive development, and the multiple intelligences potential of the students. The potential of multiple intelligences of students can be obtained through the use of a multiple intelligences' questionnaire given to students who are the subjects of the research. The material analysis is done by identifying the material to be taught, collecting and selecting relevant material, and rearranging it systematically. The analysis of the final goal is useful to restrict the researcher and prevent deviation from the initial goal of the study.

The second stage of the 4D model is the design stage where the design and preparation of products are carried out, namely the Lesson Plan and the Student Worksheet based on multiple intelligences theory. The steps for the design stage involve media selection, format selection, and the initial product design. The selection of media is related to the determination of what is the right media to present the subject matter based on the material analysis, the analysis of the students, and the available facilities at the school. The format selection includes determining the format for designing learning tools in the form of the Lesson Plan and the Student Worksheet. The initial design is the designing and writing of the Lesson Plan and the Student Worksheet so that the first drafts are obtained.

The third stage of the 4D model is the development stage which is divided into two activities, namely expert appraisal and development testing. The expert appraisal is a technique used to validate or assess the feasibility of the product design, and for this study validation was carried out by outside experts in their fields. In this study, there were four validators, two lecturers from Yogyakarta State University (UNY), and two mathematics teachers from SMK Negeri 1 Padaherang. The suggestions given were used to improve the learning tools that have been compiled. The development testing is of the product design on the target subjects and consists of two activities, namely: limited trials to find out in terms of legibility and understanding of the words and sentences used in the Student Worksheet; and the learning achievement tests as well as the spiritual attitude questionnaires and the social attitude questionnaires. Field trials were conducted to determine the practicality and effectiveness of the learning devices. 
The last stage is the disseminate stage involving a limited number of learning tools for teachers in order to obtain responses and feedback on the learning tools. If the response was good, then they would be disseminated through printing in large quantities so that the learning device can be used by a wider audience.

\section{Subjects of Testing, Time \& Research Sites}

This research was conducted at SMK 1 Padaherang in Karangsari Village, Padaherang District, Pangandaran District. The subjects of the limited trials in this study were 10 students of class XI TKJ C and the subject of field trials were 31 students of class X TPMP. The research was conducted in March-May 2015.

\section{Data, Techniques and Data Collection Instruments}

The quantitative data were obtained from the results of the expert validation, the teacher assessment questionnaire, the student response questionnaire, the observation of learning achievement, the achievement tests, the spiritual attitude questionnaire, and the social attitude questionnaire.

The qualitative data were obtained from comments and suggestions about the learning tools developed, as well as the qualitative data taken from the instruments for measuring: validity; practicality via teacher assessment questionnaires, student response questionnaires and learning implementation observation sheets; effectiveness via achievement tests, spiritual attitude questionnaires, and the social attitude questionnaires.

Validity and practicality data analyses involved converting the average score obtained into a five-scale qualitative form. The data conversion criteria can be seen in Table 2 below.

Table 2.

Data Conversion Criteria (Source: Azwar, 2013, p.163)

\begin{tabular}{cc}
\hline Interval Score & Category \\
\hline$M_{i}+1,5 S_{i}<X \leq M_{i}+3 S_{i}$ & Very good \\
\hline$M_{i}+0,5 S_{i}<X \leq M_{i}+1,5 S_{i}$ & Good \\
\hline$M_{i}-0,5 S_{i}<X \leq M_{i}+0,5 S_{i}$ & Enough \\
\hline$M_{i}-1,5 S_{i}<X \leq M_{i}-0,5 S_{i}$ & Not good \\
\hline$M_{i}-3 S_{i} \leq X \leq M_{i}-1,5 S_{i}$ & Poor \\
\hline
\end{tabular}

Data analysis techniques for the effectiveness of the learning devices in terms of achievement tests is done by determining the percentage of student completeness, while the effectiveness of the learning devices in terms of spiritual attitudes and social attitudes is by determining the percentage of students in each category.

The geometry learning devices, based on the multiple intelligences theory, are said to be:

- $\quad$ valid if the expert judgment is mostly in the good categories;

- $\quad$ practical if the results of teacher assessment and student responses are in the good categories and the learning achievement is at least $80 \%$ implemented; 
- effective in terms of achievement tests if at least $80 \%$ of students have reached the minimum completeness criteria, set by the school for geometry material, namely $75 \%$. For questionnaires on spiritual attitudes and social attitudes, geometry learning devices based on multiple intelligence theories are said to be effective if the percentage of students who attained attitudes in the high category was at least $80 \%$.

\section{Results and Discussion}

The description of the results of the development of the geometry learning device based on multiple intelligence theories using the Thigarajan, Semmel and Semmel's (1974) 4D development model is as follows.

\section{Define phase}

\section{The preliminary analysis}

Based on the preliminary analysis, the learning tools used in SMK 1 Padaherang were the results of the subject teachers' deliberations (MGMP) and only limited to the implementation plan of learning (Lesson Plan) without being supported by adequate learning media, while the learning resources used by students were the mathematics books available in the school library and even then the numbers are limited. As well, the learning tools made by the teacher did not facilitate students learning making use of the students' multiple intelligences. In relation to the implementation of the 2013 Curriculum, the learning tools that are oriented towards achieving competencies according to the 2013 Curriculum are still limited and teachers are still having difficulties in developing these learning tools.

As a result of these problems, the development of learning tools based on the multiple intelligences theory was oriented towards the achievement of competencies according to the 2013 curriculum as a possible solution to solving these problems. It was hoped that the learning tools would facilitate students' learning of mathematics and they would achieve the expected competencies based on the 2013 curriculum.

\section{The curriculum analysis}

The curriculum analysis revealed that SMK 1 Padaherang used the 2013 curriculum, and the recommended scientific approach with five main learning experiences: observing, asking, collecting information, associating, and communicating. The competencies that must be achieved by students in learning included the four core competencies namely: core spiritual attitudes (KI-1); core competencies (KI-2); core knowledge competencies (KI-3); and core skills competencies (KI-4). However, based on the results of observations and interviews with the mathematics teachers, the scientific approach had not been implemented correctly as the teachers used a more direct teaching approach as they were still having difficulties in developing learning tools whose activities used the scientific approach. Teachers also had difficulties in assessing each core competency in the 2013 Curriculum, especially the assessment of KI-1 spiritual attitudes and KI-2 social attitudes. 


\section{The student analysis}

The student analysis used as basis Piaget's development stages, where vocational students were found to belong to the formal period of operation or the stage of development of formal operations, this period begins at 12 years of age (Riyanto, 2012, p. 124). In this period students are able to think symbolically and can understand something meaningfully and can understand things that are imaginative. The implication in mathematics learning is that students can learn if the input (learning material) is in accordance with students' interests and talents. So, based on the results of observations and interviews, vocational students tended to be less enthusiastic in learning mathematics compared to the productive subjects. Students also became bored quickly when learning mathematics. This causes student achievement in learning mathematics to decline, as indicated by only $20 \%$ of students who can achieve the KKM at the end of learning.

\section{The analysis phase}

In the analysis phase, the researcher analyzed the mathematics lesson material developed in accordance with the 2013 Curriculum, and the material chosen was the geometry material of X grade semester 2 of SMK which included basic competencies (KD) 3.13, namely describing the concepts of distance and angle between points, lines and the plane through demonstration using props and other media, and 4.13 that is using various principles of $2 \mathrm{D}$ building and 3D building space and solving real problems related to distance and angle between points, lines and planes.

\section{The final goal analysis}

The final goal of learning which is the basis for the preparation of the learning tools in the form of the Lesson Plan, the Student Worksheet, an assessment instrument (achievement tests) and attitude questionnaires at this stage the learning objectives are arranged from KI-1 to KI-4.

\section{Design phase}

The design phase starts with media selection such as blackboards, markers, rulers, projectors, worksheets and teaching aids in the form of a cube frame. The Lesson Plan format was adjusted to the Lesson Plan format for the 2013 Curriculum and adjusted to multiple intelligences-based theory while the Student Worksheet was designed and printed.

The steps in developing a multiple intelligences-based Lesson Plan, involved: reviewing the syllabus and choosing geometry material KD 3.13 which was translated into 14 learning goals and KD 4.13 which was collapsed into 2 learning objectives. KD 3.13 and KD 4.13; conducting a multiple intelligence survey; selecting the type of intelligence that will be facilitated; developing learning scenarios; and, selecting the media and tools to be used in the learning.

The following is the result of a multiple intelligence survey in class X TPMP. 


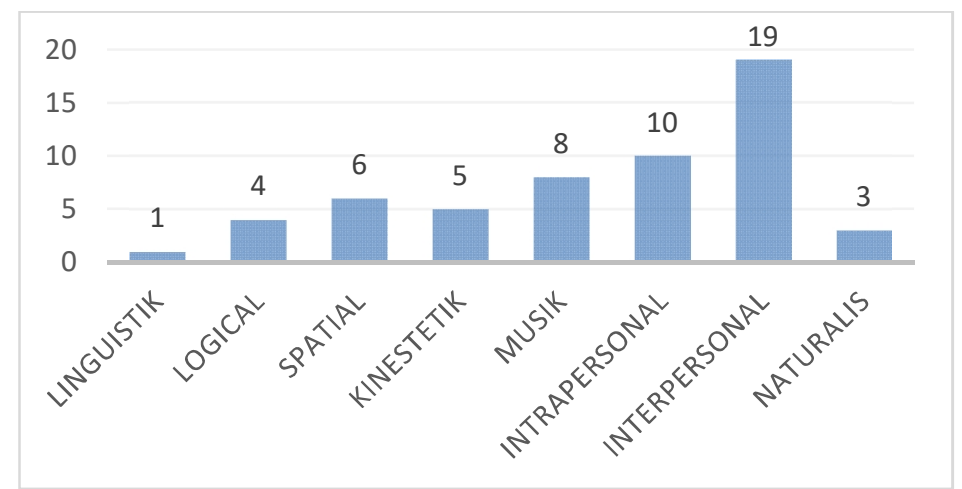

Figure 1. Compound Intelligence Survey Results.

Based on the results of the multiple intelligence survey in Figure 1, it can be seen that the most prominent intelligence in class X TPMP is interpersonal intelligence, based on this group discussion activities were chosen to facilitate interpersonal intelligence of the students, so group discussion was used at each of the six learning meetings. As well, other intelligences (at least 4) were also facilitated according to the material taught at each learning meeting.

The development of a learning scenario involves a scientific approach in which a combination of intelligences is integrated in the learning experience using the scientific approach. The researcher then designs the media and tools that will be used with the scenario such as the Student Worksheet as well as props such as reference books and other tools such as Geogebra and Corel Draw X6 applications are adapted to the needs of each meeting.

Achievement tests in this study were divided into two: a 14-question multiple choice test of knowledge competencies; and 3 descriptive problem questions intended to measure the achievement of skills competencies. The spiritual attitude questionnaire was composed of 5 positive statements and 5 negative statements and the social attitude questionnaire consisted of 9 positive statements and 9 negative statements.

The quality of achievement tests and questionnaires in this study were obtained from the validity and estimation of reliability. According to Reynolds, Livingstone \& Wilson (2010), validity is the accuracy or accuracy of interpretation of test scores. There are two validities that are carried out in this study, namely content validity and construct validity. Based on the content validity and construct validity, it was found that the achievement tests, the spiritual attitude questionnaire and the social attitude questionnaire were valid and feasible to use.

According to Reynolds, Livingston, \& Wilson (2010), reliability is the consistency or stability of the results of the assessment. Based on the analysis, it was found that the achievement tests, the spiritual attitude questionnaire, and the social attitude questionnaire were reliable and could be used in subsequent trials.

\section{Development stage}

In this study there were four validators who validated the product, two lecturers and two mathematics teachers and based on their judgment, there were several suggestions made and were used to revise the instruments. The results of the validation analysis of learning devices can be seen in Table 3 below. 
Table 3.

Results of Validation Analysis of Learning Devices

\begin{tabular}{ccc}
\hline Developed Devices & Actual Score & Category \\
\hline Lesson Plan & 3,57 & Very Good \\
Student Worksheet (Content) & 3,57 & Very Good \\
Student Worksheet (Graphics) & 3,56 & Very Good \\
\hline
\end{tabular}

From the results above, the average actual score of Lesson Plan validation is 3.57, for Student Worksheet in terms of material is 3.57, and in terms of graphics is 3.56. Based on this, it was concluded that the Lesson Plan and the Student Worksheet are valid and able to be used in mathematics learning. Then a limited trial in terms of the legibility of the instruments was conducted involving 10 students of class XI TKJ $\mathrm{C}$ as they had studied geometry. This readability included clarity of instructions, language, material and meaning of statements in the questionnaire. The results indicated that 6 students considered the readability of the developed devices to be excellent and 4 students to be in the good category. The Student Worksheet needed more pictures or illustrations and correction of typing errors. In the attitude questionnaire, several statements required explanation and the researcher revised the product before field testing.

The field trials were conducted and the practical assessment could be seen from three sources: the teacher assessment questionnaire; the student response questionnaire; and the observations. The results of the practical analysis in terms of the teacher's assessment can be seen that all categories in Table 4 were very good.

Table 4.

Results of Practical Analysis Viewed from Teacher Assessment

\begin{tabular}{ccc}
\hline Developed Devices & Actual Score & Category \\
\hline Lesson Plan & 3,57 & Very Good \\
Student Worksheet & 4 & Very Good \\
Total & 3,78 & Very Good \\
\hline
\end{tabular}

In addition, the practicality of the developed device was reviewed from the student response questionnaire given after students carry out mathematics learning using worksheets. The average student response score was 3.31, a very good category. Learning practicality in terms of learning implementation is done by calculating the average percentage of learning implementation and the results can be seen in Table 5 below

Table 5.

Results of Practical analysis in terms of the implementation of learning

\begin{tabular}{cc}
\hline Learning & Percentage of completeness \\
\hline 1 & $82,60 \%$ \\
2 & $88,46 \%$ \\
3 & $96,15 \%$ \\
4 & $100 \%$ \\
5 & $100 \%$ \\
\hline
\end{tabular}




\begin{tabular}{cc}
\hline 6 & $100 \%$ \\
Average & $94,53 \%$ \\
\hline
\end{tabular}

Based on the results of the analysis in Table 5, it was found that the percentage of learning implementation at each meeting was greater than $80 \%$ in terms of.

The effectiveness of geometry learning devices can be seen from the percentage of students' completeness on achievement imaginative things was divided into two: knowledge competency using multiple-choice tests; and skills competencies used a description test. The results of achievement tests can be seen in Table 6 below

Table 6.

Results of Student Achievement Tests

\begin{tabular}{ccc}
\hline & Multiple Choice & Description Test \\
\hline Average Score & 88,24 & 62,90 \\
Students Who Completed & 28 & 9 \\
Percentage of Students Who Completed & $90,32 \%$ & $29,03 \%$ \\
Students Who Did Not Complete & 3 & 22 \\
Percentage of Students Who Did Not Complete & $9,68 \%$ & $70,97 \%$ \\
\hline
\end{tabular}

From Table 6, $28(90.32 \%)$ students completed the multiple-choice test while in the description test only $9(29.03 \%)$ students completed. The geometry learning device is said to be effective in terms of the achievement of knowledge competencies being over $80 \%$ and not yet effective in terms of achievement of skill competencies being less than $75 \%$.

The results of the analysis of spiritual attitudes can be seen in Table 7 below.

Table 7.

Results of Spiritual Attitude Questionnaire Analysis

\begin{tabular}{|c|c|c|}
\hline Category & Number Of Students & Percentages \\
\hline Very Hight & 13 & $41,93 \%$ \\
\hline Hight & 12 & $38,70 \%$ \\
\hline Medium & 5 & $16,12 \%$ \\
\hline Low & 1 & $3,22 \%$ \\
\hline Very Low & 0 & $0 \%$ \\
\hline
\end{tabular}

Based on Table 7, it can be concluded that the geometry learning device is effective in terms of the achievement of spiritual attitude competencies.

While the effectiveness of geometry learning devices based on multiple intelligence theories in terms of achievement of social attitude competencies is shown in Table 8 below 
Table 8.

Results of Analysis of Social Attitude Questionnaire

\begin{tabular}{ccc}
\hline Category & Number Of Student & Percentages \\
\hline Very Hight & 3 & $9,67 \%$ \\
Hight & 23 & $74,19 \%$ \\
Medium & 5 & $16,12 \%$ \\
Low & 0 & $0 \%$ \\
Very Low & 0 & $0 \%$ \\
\hline
\end{tabular}

Based on Table 8 it can be concluded that the geometry learning device is effective in terms of the achievement of social attitude competencies.

\section{Conclusion}

Based on the results of this research and discussion, it was concluded that the geometry learning tools (Lesson Plan and Student Worksheet) based on the multiple intelligences theoryoriented to the achievement of competencies according to the 2013 curriculum fulfilled the criteria of validity and practicality. The geometry learning tools (Lesson Plan and Student Worksheet) were effective in terms of the achievement of spiritual attitudes, social attitudes and knowledge competencies. However, it was not effective in terms of the achievement of skill competencies. [Editors note: Due to the size of the sample the conclusions cannot be generalised beyond the current subjects. They should not be used to support an argument using different subjects].

\section{References}

Bas, G., \& Beyhan, O. (2010). Effects of multiple intelligences supported project-based learning on students' achievement levels and attitudes towards English lesson. International Electronic Journal of Elementary Education,2(3). Downloaded on $30^{\text {th }}$ November, 2014, from www.iejee.com/2_3_2010/365-385.pdf/.

Badan Standar Nasional Pendidikan, [National Education Standards Agency](BSNP) (2012). Laporan hasil UN SMA/MA tahun pelajaran 2011/2012, [Report on the results of the SMA / MA National Examination for the academic year 2011/2012]. Jakarta:

Kementrian Pendidikan Nasional Badan Penelitian dan Pengembangan Pendidikan.

Badan Standar Nasional Pendidikan (BSNP)(2013). Laporan hasil UN SMA/MA tahun pelajaran 2012/2013. Jakarta: Kementrian Pendidikan Nasional Badan Penelitian dan Pengembangan Pendidikan.

Calik, B. \& Birgili, B. (2013). Multiple Intelligence Theory for Gifted Education: Criticism and Implications. Journal for the Education of the Young Scientist and Giftedness. 1. 2147-9518. Downloaded from:

https://www.researchgate.net/publication/271832916_Gifted_children's_educations_and _a_glance_to_Turkey

Carson, A. D. (2003). Why has Gardner's Theory of Multiple Intelligences had so little impact on vocational psychology? Retrieved February 21, 2008, from http://vocationalpsychology.com/essay_10_gardner.htm. 
Gardner, H. (1995). Reflection on Multiple Intelligences: Myths and messages. Phi Delta Kappan. 77, 200-209. Downloaded on 20 February 2015, from http://learnweb.harvard.edu/WIDE/courses/files/reflections.pdf.

Indonesian Ministry of National Education (IMNE)(2003). Act Of The Republic Of Indonesia Number 20, Year 2003 On National Education System. Jakarta: Author. [Editor's note: The English version of the Act as published was originally in Bahasa Indonesia in the National Gazette Number 78 Year 2003. The original text of this Act in Bahasa Indonesia is the authentic version.]

Hoerr, T. R. (2000). Becoming a multiple intelligences school. Alexandria. ASCD.

Kemendikbud. (2013). Peraturan Menteri Pendidikan dan Kebudayaan Nomor 65 Tahun 2013 tentang Standar Proses Pendidikan Dasar dan Menengah [Minister of Education and Culture Regulation Number 65 Year 2013 concerning Basic and Secondary Education Process Standards]. Jakarta: Author.

Kemendikbud. (2014). Peraturan Menteri Pendidikan dan Kebudayaan nomor 60 tahun 2014 tentang Kurikulum SMK. Jakarta: Author.

Minister Of Education And Culture Of The Republic Of Indonesia (MECRI) (2013). Regulation Of The Minister Of Education And Culture Republic Of Indonesia Number 65 of 2013, About Basic and Middle Education Process Standards. Jakarta: Author

Minister of Education and Culture of the Republic of Indonesia (MECRI) (2014). Regulation of the Minister of Education and Culture Republic of Indonesia, Number 60 of 2014. About 2013 Curriculum Middle Vocational School / Madrasah Aliyah Vocational. Jakarta: Author

Moore, K. D. (2009). Effective instructional strategies. London: SAGE Publications.

National Council of Teacher of Mathematics (2000). Principles and standards for school mathematics. Reston, VA: NCTM.

Republik Indonesia. (2003). Undang-Undang RI Nomor 20 Tahun 2003, tentang Sistem Pendidikan Nasional [RI Law Number 20 of 2003, concerning the National Education System]. Jakarta: Author.

Reynolds, C.R., Livingston, R.B., \& Wilson V. (2010). Measurement and assessment in education. Upper Saddle River, New Jersey: Pearson Education, Inc.

Riyanto, Y. (2012). Paradigma Baru Pembelajaran: Sebagai referensi bagi Guru/ Pendidik dalam Implementasi Pembelajaran yang Efektif dan Berkualitas [New Learning Paradigm: As a reference for Teachers / Educators in the Implementation of Effective and Quality Learning]. Jakarta: Kencana.

Suyono \& Hariyanto. (2014). Belajar dan Pembelajaran: Teori dan Konsep Dasar. Bandung: Remaja Rosdakarya [Learning and (promoting) Learning: Basic Theory and Concepts]. Bandung: PT. Remaja Rosdakarya.

Temur, O.D. (2007). The effects of teaching activities prepared according to the multiple intelligence theory on mathematics achievements and permanence of information learned by 4th grade students. International Journal of Environmental \& Science Education, 4(2), 86-91.

Thiagarajan, S., Semmel, D.S, \& Semmel, M.I. (1974). Instructional development for training teacher of execeptional children. Minneapolis: Indiana University.

United Nations Educational, Scientific and Cultural Organization (UNESCO)(2012). Education For All Global Monitoring Report 2012 - Youth and skills: Putting education to work. Paris: Author

Xie, J., \& Lin, R. (2009). Research on multiple intelligences teaching and assessment. Asian Journal of Management and Humanity Sciences, 4(2-3), 106-124.

Yaumi, M. (2012). Pembelajaran Berbasis Multiple Intelligences [Multiple Intelligences Based Learning]. Jakarta: PT. Dian Rakyat. 